\title{
SHARIA LAW OF TAX AMNESTY IN PERSPECTIVE OF THE SOUTH KALIMANTAN MUSLIM ECONOMISTS
}

\author{
Firqah Annajiyah Mansyuroh \\ Fakultas Syariah, UIN Antasari Banjarmasin \\ Jalan Ahmad Yani Km. 4.5 Banjarmasin, Kalimantan Selatan \\ e-mail:firqahannajiyahmansyuroh@gmail.com
}

\begin{abstract}
Abstrak: Taraf hidup masyarakat yang meningkat akan diperlukan anggaran yang selalu meningkat pula. Hal ini dapat dilihat dari besarnya anggaran pemerintah Indonesia untuk tahun 2016. Belanja Negara dalam APBN 2016 sebesar Rp 2.095,7 triliun meningkat dari tahun 2015 yang hanya sebesar Rp 2.039,5. Sedangkan untuk tahun 2017, pendapatan dalam APBN hanya Rp 1.750,3 triliun sedangkan belanja mencapai Rp 2.080,5 triliun. Salah satu cara untuk meningkatkan penerimaan negara tanpa menambah beban baru kepada masyarakat, dunia usaha, dan para pekerja adalah melalui program pengampunan pajak. Dari aspek hukum, khususnya peraturan perundang-undangan, persoalan pengampunan pajak (tax amnesty) mengandung legitimasi mengenai tidak memberlakukan peraturan perundang-undangan yang berlaku, terutama tentang sanksi administrasi, sanksi pidana dan bentuk hukum pengaturan pengampunan pajak itu sendiri. Dari aspek hokum Islam, kebijakan pengampunan pajak ini tidak bisa diabaikan melihat unsur maslahat dan mafsadat atau efek dominan yang ditimbulkannya di tengah masyarakat. Penulis merasa pentingnya kajian kotemporer mengenai kebijakan fiskal dalam ekonomi Islam diperhatikan serta mendapatkan persetujuan dari para ahli serta cendikia dibidangnya. Oleh karena itu, penulis menganggap ekonom muslim adalah orang yang tepat untuk dikonsultasikan mengenai kebijakan tax amnesty, sehingga penelitian tentang perspektif tax amnesty Ekonom muslim Kalimantan Selatan dilakukan. Penelitian ini merupakan penelitian hukum empiris, yaitu penelitian yang dilakukan di lingkungan tertentu, dalam hal ini dilakukan di Provinsi Kalimantan Selatan. Hasil yang ditemukan adalah para ekonom Muslim Kalimantan Selatan memiliki pandangan yang terbagi menjadi dua dalam hal kebijakan tax amnesty, yaitu setuju dan tidak setuju. Mereka yang setuju dengan kebijakan ini memiliki pendapat bahwa kebijakan imam (pemerintah) ini berdasarkan maslahat (kemanfaatan) dan mempertimbangkan jumlah manfaat yang diperoleh dibandingkan dengan jika tidak diampuni (tidak amnesty pajak).
\end{abstract}

\footnotetext{
Abstract: The rising standard of living will require an ever-increasing budget. This can be seen from the size of the Indonesian government budget for 2017, revenue in the APBN only Rp 1750.3 trillion while spending reached Rp 2,080.5 trillion. One way to increase state revenues without adding a new burden to the community is through a tax amnesty program. This policy then from the legal aspect, especially the tax amnesty legislation contains legitimacy about not enforcing the applicable laws and regulations, especially regarding administrative sanctions, criminal sanctions and legal form of tax
} 
amnesty arrangement itself. From the legal aspects of Islam, this policy of tax amnesty cannot be ignored to see the elements of maslahat and mafsadat or the dominant effect it causes in society. Therefore, author consider the Muslim economist is the right person to be consulted about the policy of tax amnesty, so that the research on tax amnesty perspectives Muslim economist South Kalimantan conducted. This research is empirical law research, which is research done in certain environment, in this case done in South Kalimantan Province. The results found are Muslim economists of South Kalimantan have a view that is divided into two in terms of tax amnesty policy, namely agree and disagree. Those who agree with this policy have the foundation of the priestly (government) policy on the people based on the benefits and considering the amount of benefits obtained compared to the non-tax amnesty.

Keywords: Tax Amnesty, Islamic Economic Law, South Kalimantan

\section{Preliminary}

Rising standards of living that would be required budgets always increase. It can be seen from the Indonesian government budget for 2016. Expenditure in the Budget 2016 to $\mathrm{Rp} 2095.7$ trillion increase from 2015 which was only Rp 2039.5. As for 2017, revenues in the state budget is only Rp 1750.3 trillion, while spending reached Rp 2080.5 trillion. ${ }^{1}$ The state's revenues from year to year is always increasing, but still not balanced by the increase in public expenditure.

One way to increase revenues without adding a new burden to the people, businesses and workers is through tax amnesty program. This policy is expected to increase tax subjects and objects of taxation. Taxpayer may be the return of funds that are outside the country, while on

${ }^{1}$ APBN, https://www.kemenkeu.go.id/apbn2016; https:// www.kemenkeu.go.id/apbn2015. Accessed at 12:35 pm March 1, 2018. the side of tax object in the form of increasing the number of taxpayers. ${ }^{2}$

Even so, the efforts of Indonesia Directorate General of Taxation to grant a pardon to the taxpayer or the taxpayers still tinged with the pros and cons of the various parties. Indonesia's tax amnesty program has conducted twice, in 1984 and 2008. Implementation of the tax amnesty in 1984 was a failure for these programs because their implementation is not effective, the response time of the taxpayer is very less and not followed by reform of the tax administration system as a whole. Meanwhile, in 2008 there was an increase of 5.6 million new taxpayers, but after that the level of tax compliance stagnated, tax revenues go down, and so does the tax ratio that does not rise significantly ${ }^{3}$

\footnotetext{
2 Ragimun, "Analisis Implementasi Pengampunan Pajak (Tax Amnesty) Di Indonesia," Badan Keuangan Fiskal Kemenkeu RI, n.d. p. 3 .

3 Safri, "Efektifitas Program Tax Amnesty Dan Faktor Keberhasilannya: Pembelajaran Dari Negara-Negara Yang Pernah Menerapkan," Jurnal Mitra Manajemen 8, no. 2 (2016): 105-20. p. 107.
} 
From the aspect of the law, particularly legislation, the question of remission of taxes (tax amnesty) containing not impose the legitimacy of the legislation in force, especially concerning administrative chastisement, criminal punishment, and the legal form of tax amnesty arrangement itself. Providing incentives especially in the realization of tax amnesty will cause various effects of injustice (inequitable) because only certain taxpayers who will receive or enjoy it, prone to be abused, and tax incentives as government subsidies will result in a loss of potential revenue from the tax sector.

From the aspect of Islamic law, this tax remission policy can not be overlooked see elements of beneficiaries (maslahah) and mafsadat or dominant effect it has on society. The issue of fiscal policy, especially tax amnesty is included novelty in jurisprudence because this issue has not been discussed in the books of Islamic jurisprudence, especially classical fiqih. However, due to tax amnesty it is not contained in textual sources of Islamic law, nor never previously practiced by the Prophet and the four khalifah, that author feel the need to conduct legal research related to tax amnesty issue in the eyes of Islamic economic laws.

Author feels the importance of the contemporary study regarding fiscal policy in the Islamic economic concern and also get approval from the experts and scholars in their field. As a Muslim is required to find out the truth of everything that there is no doubt in it. It is necessary to ask for an explanation from those who have knowledge (intellectual Muslim) in providing an explanation about them as a person who has a social responsibility. As Allah says in Al-Nahl: 43 "then ask the person who has knowledge if you do not know". Therefore, author considers Muslim economists are right to be consulted about the tax amnesty policy. They are professionals in the disciplines of sharia socio-economic study. Therefore, consider the Muslim economist is the right person to be consulted about the policy of tax amnesty, so that the research on tax amnesty Muslim perspectives economist South Kalimantan conducted.

Based on this background, the researchers wanted to examine the concept of taxation and tax forgiveness in Islam, through a study entitled: "Sharia Law of Tax Amnesty in Perspective of the South Kalimantan Muslim Economists".

\section{Method}

This research is empirical juridical law. Thus, the juridical empirical approach in this research means is that in analyzing the problems made by combining the ingredients of the law (which is a secondary data) with the primary data collected in the field, namely on how the Muslim economist 
South Kalimantan view on tax amnesty. ${ }^{4}$

Data collection methods used by the author in this study are:

1. Research Library (Library Research) is a research method that is done by reading books of literature in order to obtain, collect data and assess the more accurate data to assist authors in developing topics related to the headline writers choose.

2. Research Field (Field Research) that author conducted interviews (interview) directly on the object of research. That is a direct converse with Muslim economists South Kalimantan by asking questions to obtain information or explanation which more accurately in order to obtain a more objective conclusion.

Mechanical determination of informants drawn by researcher is purposive sampling. As the name implies, the informant is taken with the intent or purpose. Someone or something sampled because researcher believe that someone or something that has the necessary information for research. The interview is a process of questions and answers in ongoing research orally in which two or more face-to-face hearing directly information or details. ${ }^{5}$

4 Amiruddin and Zainal Asikin, Pengantar Metode Penelitian Hukum (Jakarta: Grafindo Persada, 2010). p. 133.

${ }^{5}$ Cholid Narbuko and Abu Achmadi, Metodologi Penelitian (Jakarta: Bumi Aksara, 2001). p. 81.
Interviews were conducted in an unrestricted answer, open by using a list of questions that have been prepared (as an interview guidelines) in accordance with the problems to be sought answers without the possibility to add other questions spontaneous connection with the answers given by the respondents. Interviews conducted only on selected respondents hereinafter called the informant, who represent the Muslim economists in South Kalimantan. Respondents of this research is Muslim economists that mature in experience and ability, they were appointed because of its competence.

In conducting the field research, researcher will bearing interviews to:

1.Prof. Muhammad Handry Imansyah, MAM, Ph.D. Professor of ULM Banjarmasin.

2.Dr. Umi Hartin Anisah, SE. MM. Chairman of the Forum for Economic and Business Lecturer Islamic South Kalimantan.

3.Dr. Muhaimin SA, MA. Chairman of the Association of South Kalimantan Islamic Economics and a lecturer at UIN Antasari Banjarmasin.

4.Muhammad Hudaya SE. MM. Ph.D. Chairman of the Economic Community of Sharia who is also a lecturer at ULM Banjarmasin.

5.Dr. Mahmud Yusuf, SHI, MSI. UIN Antasari Banjarmasin lecturer. 
6.Syahrituah Siregar, SE. MA. is not only an obligation, but it is the Banjarmasin Lambung right of every citizen to participate in Mangkurat University lecturer, the form of participation in state who also serves as Independent financing and national development.. ${ }^{6}$ Commissioner of Bank Kalsel.

7.Lutfi Sahal, S.HI, MSI, lecturer at UIN Antasari Banjarmasin.

8.Muhammad Noval, SEI, M.SI, a permanent non-civil servant lecturer at UIN Antasari Banjarmasin

9.Ahmad Fatrya Putra, head of the branch Bank KalSel Syariah who is also Chairman of the Association of Bank Syariah Indonesia South Kalimantan.

\section{Result and Discussion}

Tax is a source of state income that is very important in sustaining state expenditure financing. Almost every country in the world collects taxes on its citizens. The size of the tax levy depends on the policies of each country in managing finances and economics. Tax is a compulsory contribution to a country that is owed by an individual or a compelling entity based on the Law, by not getting compensation directly and used for state purposes for the greatest prosperity of the people. Tax payments are a manifestation of state obligations and the role of taxpayers to directly and jointly carry out tax obligations for state financing and national development. In accordance with the philosophy of the tax law, paying taxes

Tax amnesty is a policy offered to disclose all income or assets that have not been reported, pay ransom as a penalty, add revenue to the state and encourage voluntary compliance. With the opportunity offered, the taxpayer begs forgiveness from the government for dishonesty in filling out the tax form and promises to be obedient. This policy is expected to be able to obtain a significant additional revenue in the short term, relatively short time and not to incur large costs.

But for the community, however forgiveness is given, tax is still considered a burden, given the obligation to pay taxes which in turn will reduce the purchasing power of the person, especially when compared to having no obligation to pay taxes. For economists, the tax amnesty policy is not merely a government tool to meet funding needs, but also to influence people's behavior, both economic and psychological behavior. The burden on the community on the one hand and the potential for considerable revenue on the other hand for the government often makes the benefits and role of tax amnesty seen differently, in accordance with the perspective of each party.

6 "Belajar Pajak | Direktorat Jenderal Pajak," accessed October 9, 2017, http://www.pajak.go.id/content/belajarpajak. (10 Oktober 2017) 
So what is the Tax Amnesty policy in Islam (sharia law)? So the abtraction or interpretation of the knowledge circles is that Muslim economists whose concentration of study is economic and intense with Islamic economic studies or have experience in the field of law in Islamic economics need to be done to see how this Tax Amnesty policy concept.

\section{The Existence of Tax Amnesty Program: Perspective of the South Kalimantan Muslim Economists}

One of the government's policies in the tax fiscal field is the tax amnesty program, which is regulated in Law Number 11 of 2016 concerning Tax Amnesty. Tax amnesty allows individuals or entities to pay off tax obligations that they had not previously fulfilled, without having to be threatened by some or all of the financial penalties or confinement that normally applies if tax evasion occurs. The policies adopted by the government of a country, the longterm goals are increasing the number of taxpayers and increasing voluntary compliance.

The implementation of Indonesia's tax amnesty program is considered by many to be the most successful tax amnesty in the world. Finance Minister Sri Mulyani Indrawati revealed data on the achievement of the tax amnesty program as the most successful in the world, with total property declarations reaching Rp4,414 trillion and ransoms of Rp105 trillion. Positive comments were also conveyed by tax observers as well as CITA Executive Director, Yustinus Prastowo, who stated that the achievement of tax amnesty in Indonesia, measured by the value of assets and ransom statements, was the highest in the world. Angel Gurria, Secretary General of the Organization for Economic Cooperation \& Development (OECD) or the Organization for Economic and Development Cooperation, appreciates the Tax Amnesty Program in Indonesia with the achievement of the property statement value of more than Rp 2,000 trillion in the first period of 2016. JP Morgan Financial Consultants, assessing the achievement of the implementation of the tax amnesty program currently underway in Indonesia has far exceeded the initial market expectations for property statements in the range of US \$30-US $\$ 50$ billion or around Rp. 400 trillionRp. 700 trillion (US $\$ 1=$ Rp. 13,200). ${ }^{7}$

From the report since the end of the 2016-2017 tax amnesty program, there are a number of things that have been achieved by the policy, including the tax amnesty program in Indonesia which is the most successful in the world compared to Italy, Chile and South Africa. Indonesia managed to collect assets reports of Rp. 4,881

\footnotetext{
7 Khoiril, "Taz Amnesty Dan Moral Hazard: Studi Reformulasi Undang-Undang Tax Amnesty 2016 Untuk Mencegah Moral Hazard Wajib Pajak" (Surakarta, 2017).
} 
trillion, while Italy made Rp1, 179 trillion, Chile Rp.263 trillion, and South Africa only Rp. 115 trillion. In addition the tax amnesty program has saved state taxes that have been hampered so far. Its success can increase the state treasury. If cash increases, the development program launched by the government will run smoothly. Tax amnesty is also a big capital to achieve increased compliance performance in the future. The expansion of the database and efforts to maintain tax compliance from participants of the tax amnesty allows a change in the structure of tax revenue which is the beginning of a comprehensive tax reform. ${ }^{8}$

Fatrya, one of the Muslim economists in South Kalimantan, views this policy as a way for the government to attract public funds that have been parked in other countries' banking, he said, "The purpose of this tax amnesty is in the framework of one of the sources of state revenue to finance development. With the hope that entrepreneurs who have large funds abroad are urged to do tax amnesty. Then the funds can enter, then adjusted to the government program, until the completion of this program. We see from the point of view of the government, seeing it positively, entrepreneurs who have large funds, who are deposited abroad, may be

${ }^{8}$ Adhitya Himawan, Inilab empat keberbasilan tax amnesty, (Jakarta,

2017)

https://www.suara.com/bisnis/2017/05/17/205648/inilahempat-keberhasilan-program-tax-amnesty afraid of being taxed or otherwise, then tax amnesty is applied, and then will be monitored closely enough so that later, when the program is completed, It is expected that all funds abroad can be used domestically for development, where development is certainly for the community as well. As long as you not kemplang the money." 10

Agreeing with Fatrya, Syahrituah Siregar also argued, "Tax amnesty, the aim is that money abroad is withdrawn to the country, so that domestic liquidity can be good. Then it extends to tax order. Effectiveness in terms of attracting funds abroad usually fails, but even so, Indonesia's figure is quite successful compared to foreign countries, but still far from the nominal that you want to achieve or from the potential that exists."11 But he regretted this policy because according to him tax amnesty became no longer strategic because small taxpayers were also subjected to tax intensive, whereas according to Syahrituah, only those who had a very large amount of assets should be targeted.

Still in line with the opinion of Fatrya and Syahrituah, Handry views the tax amnesty program by saying, "the tax amnesty policy is actually to achieve the potential tax that has been outside the system. So there are those

\footnotetext{
${ }^{9}$ Kemplang has two meanings, namely avoiding having to pay and taking non-rights by not giving them the right to own. Fatrya here uses the word kemplang which means the tax collector officers take a number of assets which should be included in the state treasury but instead put them into personal cash so that the state loses.

${ }^{10}$ Interview with Fatrya Putra, 5 June 2017.

${ }^{11}$ Interview with Syarituah Siregar, 6 June 2017.
} 
who report the tax under what they should, then many are the term entrepreneurs who do transfer pricing ${ }^{12}$. So the goal (tax amnesty) broadens the tax base to enter the system. Next year all countries exchange information ${ }^{13}$, so it's good to ask forgiveness now. The tax amnesty target is actually the circle of rich people. So it benefits more for the people and the country. This also actually teaches us honestly."14

Whereas Mahmud Yusuf explained, "so that the tax amnesty is made by the government with the assumption (assumption before taking a policy) that our country has many Indonesians to save their funds abroad. How can the funds parked abroad be withdrawn to Indonesia? Then the tax amnesty policy is used. People who do not report their assets, the impact is that

\footnotetext{
12 Transfer pricing is a company policy in determining the price of transfer of a transaction whether it is goods, services, intangible assets, or even financial transactions carried out by the company. The transaction itself can be done in one country (domestic transfer pricing), as well as with different countries (international transfer pricing). Handry here uses the term transfer pricing connoted with something that is not good (often called abuse of transfer pricing), which is a transfer of income from a company in a country with a higher tax rate to other companies in a group in a country with more tax rates low thus reducing the total tax burden of the group company.

13 Automatic Exchange Of Information (AEOI) in accordance with the press release number 25 / KLI / 2016 dated 2 (two) May 2016 by the Ministry of Finance of the Republic of Indonesia, Indonesia will conduct international cooperation in the field of information exchange for taxation purposes which is one of the global initiatives in a series of efforts to overcome the world financial crisis. The Government of Indonesia will implement AEOI with 94 (ninety-four) other jurisdictions that will be effective since September 2018. Here Handry asserts that if automatic exchange of information has occurred, it will be more difficult for taxpayers because all assets both domestically and abroad will be able to known by the authorities. Therefore according to Handry it is better to use a tax amnesty facility while still being given the opportunity.

14 Interview with Muhammad Handry Imansyah, 25 June 2017.
}

they do not pay taxes, then how do people who do not recognize their assets abroad can be returned to Indonesia. The goal is to maslahah. If there is no law on tax amnesty, the Indonesian property remains parked abroad. The consideration is, to forgive people who are "sinful" (not paying taxes or not reporting assets according to the original), or not benefiting at all from the money that is abroad for the benefit of their own country. Because it is even worse if the funds remain abroad. There is income that is not reported abroad, more difficult, than forgiving the person for entering his money domestically."15

Muhaimin's maslahah view was also given, he said, "the government has run out of ideas, which how taxpayers can pay a one-hundred percent tax (all tax-compliant), in this case employers become the most tax-arrears. So for the benefit of the general public and how this tax can be withdrawn, I think that this tax amnesty or tax amnesty is legitimate. Moreover, the concept in general can be accepted in various countries. As far as I know, the concept of forgiveness is in all areas of law. So forgiveness is part of something that naturally exists. Tax amnesty from origin is made for public benefit, its okay. And in Islam there is also forgiveness that is for balance with sanctions and concessions. Same is in

\footnotetext{
15 Interview with Mahmud Yusuf, 19 June 2017.
} 
the realm of law there is an exception."16

While Lutpi Sahal sees that the tax amnesty policy is precise by the government, he said, "amnesty of taxes has its positive and negative. The positive state is helped, the government gets additional taxes. The negative is that if the company is not fined as it should be and instead is forgiven, then we experience a loss from this forgiveness. But if it is not forgiven, then it is likely that they will not pay taxes. Forgiven they will want to pay because of the tax amnesty relief. So in this way the government takes the policy to forgive those who are actually guilty (not paying taxes or not reporting property properly) so it is right (the policy) of the current government." 17

The opinion of the Muslim economists in South Kalimantan above is based on the rules of ushuliyyah and fiqhiyyah such as:

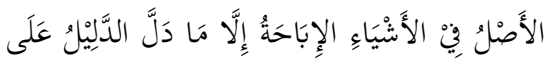

خِاَلَفِ

"In principle, every thing (outside worship) is permissible unless there is an argument that shows otherwise".

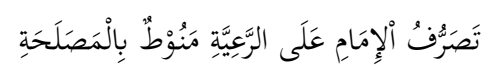

"The policy of the imam (government) towards the people is based on maslahah (benefit)."

$$
\text { الضَّرَرُ يُزَالُ }
$$

${ }^{16}$ Interview with Muhaimin, 19 July 2017

${ }^{17}$ Interview with Lutpi Sahal, 22 June 2017.
"The harm (mudharat) must be eliminated."

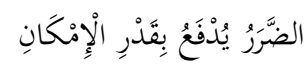

"All harm (mudharat or danger) must be avoided wherever possible"

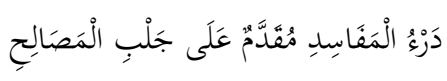

"Avoiding harm (mudharat or danger) are above interpretations to brings benefits (maslahab)"

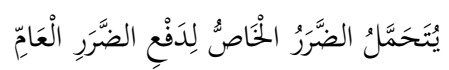

"A special dharar must be borne to avoid general dharar (wider)."

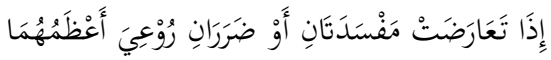

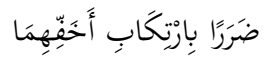

"If there are two conflicting damages or dangers, then greater damage or danger is avoided by committing an act that risks less harm."

Even so some ushul experts argue that maslahat cannot be used as a legal basis or is used as a proposition unless the Shari'a recognizes it. Other ushul experts argue that maslahat can be used as a legal basis as long as there is no argument against it. Because the problems of life have never ceased to appear, and the benefits are also increasing. If welfare cannot be used as a legal basis, legal proceedings will stop and many legal issues will not be resolved. ${ }^{18}$

Khallaf in Al-Ijtibad fi Asy-Syariah Al-Islamiyyah argued that building legal provisions based on merit is a feature of the flexibility of Islamic law.

18 Abdul Wahhab Khallaf, Ijtibad Dalam Syariat Islam, ed. Rohidin Wahid (Jakarta: Pustaka Al-Kautsar, 2015). p. 273. 
Because according to him, every problem that arises and is needed by the environment, must find a solution in the Shari'a, as long as the benefit really exists, not just an allegation and desire for lust alone. The maslahat must also be public, not personal. Khallaf also said that if the Companions of the Prophet, Tabi'in, and the Mujtahid establish the law by realizing the benefits, they think to bring benefits and keep away from harm. ${ }^{19}$

The problem of this policy is not only limited to the requirement of requiring a requirement from the mandatory, because there are general rules and general principles of sharia law that are used as the basis for taking by Muslim scholars from the sharia texts and the conclusions of their special laws. Thus the rules become the main principle for implementing policies and deciding a problem. From the rules arise the term, such as maintaining public interest, rejecting the language takes precedence over the benefits of two things that are equally beneficial, choosing something less dangerous than the two conditions which are equally dangerous.

Author reviews from the opinion of Imam Ghazali who is a Syafi'i scholar in which he is a scholar who uses very little rules of mashalih almursalah (on the basis of interest). $\mathrm{He}$ said that if the state treasury is empty and there are no sufficient costs to pay for military expenses while the enemy

${ }^{19}$ Khallaf. p. 274-275. enters into an Islamic state, or the growing uprising from those who mean evil, then the head of state may collect fees from the rich. Because we know that when two dangers arise the sharia law requires rejecting a greater danger. ${ }^{20}$

This is in line with the opinion of Imam Syatibi who is a follower of the Maliki school in his book لاعتصام who said, 'if we compare this dharar (taking part of the property) with dharar that might arise (if the power falls in the hands of the enemy), then they (state leaders) have the right to take property here. It seems not to be debated to consider the second dharar more than the first dharar. We clearly understand this from the purpose of the Shari'a, before looking at the amplifier. ${ }^{2122}$

So the opinion of Ghazali and Syatibi that allows the authorities to take policies in taking their people's property for the sake of the state in certain situations is based on the principle of "the obligation to carry little danger to avoid greater danger". Therefore, the South Kalimantan Muslim economists above, such as Muhaimin, Fatrya, Syahrituah, Handry, Mahmud, and Lutpi, have the same understanding that the tax amnesty policy ia as part of a policy that prioritizes benefit and prevents

${ }^{20}$ Al-Ghazali, Al-Mustashfa Min Ilmi Ushul, 1st ed. (Beirut: AlResalah Publishing House, 1997). Juz 1. p. 426

${ }_{21}$ Abu Ishaq Ibrahim bin Musa bin Muhammad Al Lakhmi Asy-Syatibi, Al- ¿'tishâm Juz 3 (Dar Ibnu Al Jawzi, 2008). p. 22.

22 Abu Ishaq Ibrahim bin Musa bin Muhammad Al Lakhmi Asy-Syatibi, Al- ${ }^{\prime}{ }^{\prime} t i s h a ̂ M$, ed. Edy Fr and Fajar Inayati (Jakarta: Pustaka Azzam, 2006). p. 668. 
poverty. The Indonesian government when issuing a tax amnesty policy is not only based on the notion that the Indonesian people whose assets are kept abroad do not report correctly, but are based on reports from the McKinsey study ${ }^{23}$ that there are 250 (two hundred fifty) billion US dollars or Rp. 3,250 (three thousand two hundred fifty) trillion rupiahs of wealth of Indonesian conglomerates abroad. Of that figure, there are Rp.2, 600 (two thousand and six hundred) trillion rupiahs deposited in Singapore in the form of deposits, capital and fixed income ${ }^{24}$.

From the report, according to Muhaimin, Fatrya, Syahrituah, Handry, Mahmud, and Lutpi, it would be worse if it was not forgiven by the delayed tax payment, so the state could not use the funds for the benefit of the public at large. Conversely, if forgiven, the state will benefit in terms of the flow of funds that will be expected in the state treasury will be more income and ultimately its use is for the benefit of the country, namely the welfare of many people.

Meanwhile, Noval considers that there is an injustice to this tax amnesty

\footnotetext{
23 McKinsey \& Company is a multinational management consulting company. The company is a consultant for $80 \%$ of the largest companies in the world and is considered one of the most prominent consulting management companies. See the official McKinsey \& Company website https://www.mckinsey.com/.

24 Fixed income here does not mean literally 'fixed income' but economic terms to refer to bonds or debt. Fixed income or bonds is debt but in the form of security, namely a statement of debt from the bond issuer to the bondholders along with a promise to repay the principal and interest coupons later on the payment due date.
}

policy. Noval said, "If there is a tax amnesty there will certainly be a procons. Pro, funds abroad can be state revenue because there are taxes, and also to increase the rate of economic growth, it can be for bonds used for Indonesia's development. The cons is because as if due to tax amnesty, people who from the beginning were not respected. So those who are disobedient are even forgiven, while the obedient ones have no appreciation. I think to be fair, the obedient ones should be given appreciation." 25

Likewise with Hudaya who argued that the tax amnesty policy was actually more beneficial for those who were guilty and the benefits felt by the state were only a little. Hudaya said, "This tax amnesty is not fair. Those who pay taxes, billions, trillions, are forgiven by paying only this year. But when we are obedient, then we can be late. This extends not only to the rich, but also to the small community and Micro, Small and Medium Enterprises (UMKM). If we look at the background of the publication of the law on tax amnesty, it means that those who benefit are those who are big tax evaders. The country benefits only a little."26

Hartin Umi Anisah's thoughts on tax amnesty are also in line with Hudaya's thoughts, Hartin said "Tax amnesty is causing contradiction. Small people also get hit. Even though tax

\footnotetext{
${ }^{25}$ Interview with Muhammad Noval, 20 June 2017.

${ }^{26}$ Interview with Muhammad Hudaya, 14 June 2017.
} 
evaders commit crimes. If tax amnesty is applied again, those who commit tax crimes think of 'ah, it's okay for us to be forgiven later'. So that a system like this actually creates opportunities for people to commit crimes. Tax amnesty is different from forgiveness in Islam. Different treatment with Islamic law. In Islam, the law makes people deterred and thinks twice about committing a crime. But tax amnesty, people even think of committing a crime assuming later it will be forgiven. If indeed what you want to wear is people who just pay taxes, then you should be entrepreneurs or rich people who are simply called and told to pay off their tax debt. If all this is like this, then the losers will be the small people. The mudharat in my opinion is even more. Because this does not only affect the present and not only to certain people. That's why not all policies are equally hit like this should be taken." 27

The thought of Noval, Hartin and Hudaya regarding the injustice of the tax amnesty policy based on the guidance of justice for the community from a leader in this case the government in accordance with the Shari'a. This is in accordance with the rules fiqhiyyah that is:

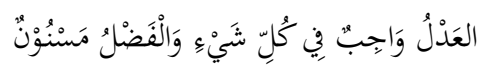

"Al-'adl (justice) is obligatory on everything and al-fadl (additional) is Sunnah".

${ }^{27}$ Interview with Hartin Umi Anisah 8 June 2017.

$$
\text { هَمْْم مَالَنَا وَعَلَكْهِمْ مَا عَلَيْنَا }
$$

"For them there are rights such as the rights that exist in us and to them are burdened with obligations such as the burden of obligation to us". 28

Q.S. Al Hujurat/49: 9;

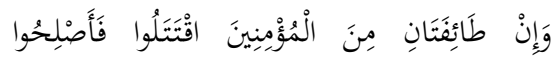

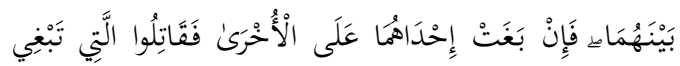

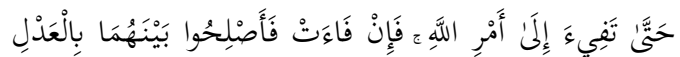

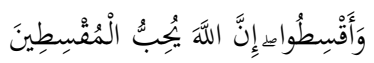
"and if two parties of the believers quarrel, make peace between them; but if one of them acts wrongfully towards the other, fight that which acts wrongfully until it returns to Allah's command; then if it returns, make peace between them with justice and act equitably; surly Allah loves those who act equitably." 29

As in the hadith number 1329 Tirmidhi's history reads,

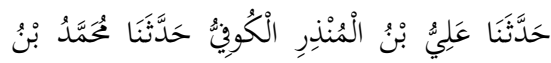

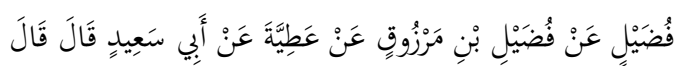

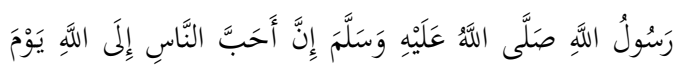

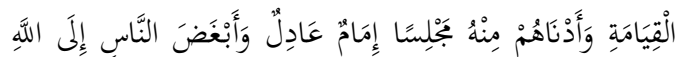

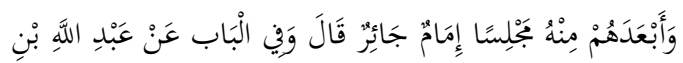

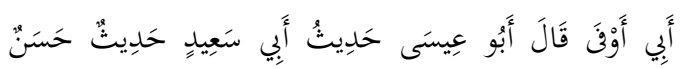

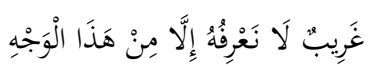
'had told us Ali ibn Al-Mundzir AlKufi, had told us Muhammad bin

28 A Djazuli, Kaidah-Kaidah Fikih Islam (Jakarta: Kencana, 2007). h. 153.

${ }^{29}$ Departemen Agama RI, Alquran Dan Terjemahannya. h. 517. 
Fudlail of Fudlail bin Marzuq from 'Athiyyah from Abu Sa'id he said; The Messenger of Allah sallallahu 'alaihi wasallam said:" indeed the man who is most loved by Allah and the closest to his seat on the Day of Judgment is the just leader, while the human being is most hated by Allah and the farthest seat is the farthest leader ' $(\mathrm{H}$. Tirmidhi). He said in this case there was a similar hadith from Abdullah bin Abu Aufa. Abu Isa said, the Hadith of Abu Sa'id is a hasan gharib hadith, we do not know except from this path'. 30

Then the hadith number 6806 in the Chapter of Virtue Leaves the Book of Hudud's Sin in Sahih Bukhari, which is also found in Sahih Muslim number 10312, Tirmidhi number 2391, and Nasa'i number 5380, which reads,

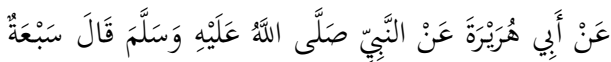

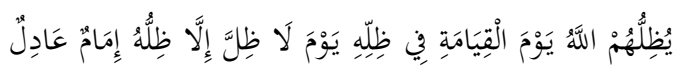

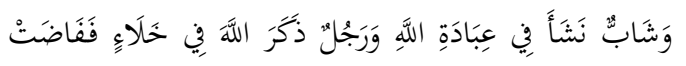

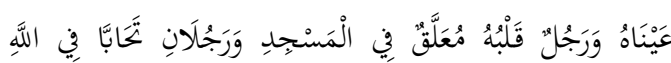

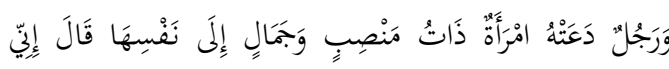

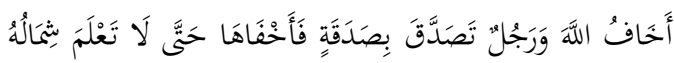
مَا صَنَعَتْتُ يَيْنُهُ

'Abu Hurairah said that the Prophet sallallabu 'alaibi wasallam said,' there are seven kinds of people who will take shelter under the auspices of Allah, in the heart of no shade except the shade of Allah: 1) the fair (justice) Imam (leader), and 2) the youth who

${ }^{30}$ Muhammad bin Isa At-Tirmidzi, Sunan Tirmidzৃi (Riyadh: Maktabatu Al Ma'arif, n.d.). p. 314. diligently worship Allah, 3) the dhikr remembers Allah alone to shed tears, 4) people whose hearts are always attached to the mosque, 5) two people who love each other because of Allah, 6) the men invited to commit adultery by beautiful nobles, then reject the word: I am afraid of God. And the person who is giving alms secretly until his left hand does not know what his right hand is giving up' (H.R. Bukhari, Muslim, Trimidzi and Nasa'i). ${ }^{31}$

Allah says in Q.S. Shaad/38: 26,

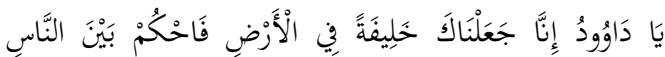

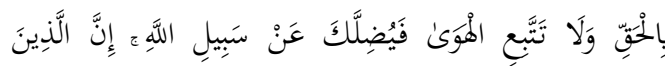

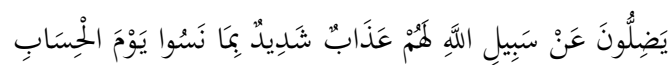
'O Dawood! Surely We have made you a ruler in the land; so judge between men with justice and do not follow desire, lest it should lead you astray from the path of Allah; (as for) those who go astray from the path of Allah, they shall surely have a severe punishment because they forgot the day of reckoning'. 32

To see how far a government has been fair to its people, it can be seen through decisions and policies issued. When applying the law equally and equally to all its citizens who do wrong or violate the law, without choosing,

\footnotetext{
${ }^{31}$ Muhammad bin Ismail Al Bukhari, Shahih Bukhari (Beirut: Dar Ibn Katsir, n.d.). p. 163.; Muslim bin al Hajjaj bin Muslim bin Kausyaz al-Qusyairi An-Naisaburi, Shabih Muslim (Dar Al Mughni, 1998) p. 514; Muhammad bin Isa AtTirmidzi, Sunan Tirmidri (Riyadh: Maktabatu Al Ma'arif, n.d.) p. 539.; Abu Abdurrahman Ahmad bin Syua'ib bin Ali Annasai, Mukhtabar Min Sunan Nasa'i (Riyadh: International Ideas Home, n.d.). p. 545.

${ }^{32}$ Departemen Agama RI, Alquran Dan Terjemahannya. p. 455.
} 
the leader can be said to have done justice. But on the contrary, if the leader only punishes some people (ordinary people) but protects some others (elite or conglomerate), even though they are both breaking the law, then the leader has done wrong and is far from fair behavior. On that basis, then some Muslim economists in South Kalimantan consider this policy unfair because according to them they benefit more from those who tax the conglomerate than the ordinary people who obey the tax. In fact, they view the state as benefiting only very little compared to the profits taken by the journalists with the existence of this tax amnesty.

Imam Nawawi rahimahullah also been at loggerheads because they think it's unfair the current leader in tax collection. Sham Sultan lived in luxury while people are asked to pay taxes because the state treasury is empty but when it was set on fire. At that time there was an attack massive Tartar troops to the territories of the Muslims, almost all the territories of the Muslims have conquered by the Tatar troops. Sham ruler at that time was Sultan Zahir Baibas. He invited the scholars to deliberation in the face of Tatar troops, being cash in Baitul Maal insufficient for war. Finally they determined that the state will collect taxes to the people, especially the rich to help the cost of war. ${ }^{33}$

${ }^{33}$ Imam Jalaluddin Al-Suyuthi, Husnul Mubadharah Fi Tarikh

Turns Imam Nawawi is not present in the show, so it raises a question mark for the Sultan. Imam Nawawi then finally called. Sultan said to him, "Give me your signature along with other scholars". But Imam Nawawi not willing. Sultan asked Imam Nawawi, "Why you resist?" Imam Nawawi said: "I know that the Sultan was once the slave of Amir Banduqdar, you do not have anything, then God gives wealth and the king maketh, I hear you have a thousand slaves. Each slave has oversized clothes of gold, and you also had 200 jariah, every jariah have jewelry. If you have means to spend it all, and servant was wearing only woolen cloth alone instead, as did the jariah only wear clothes without jewelry".34

The view of injustice in the tax law in tax amnesty policy is reinforced by the results of research by Safri in his Efektifitas Program Tax Amnesty Dan Faktor Keberhasilannya: Pembelajaran Dari Negara-Negara Yang Pernah Menerapkan. Safri examine the state had to apply tax amnesty like, Belgium, France, Ireland, Italy, Switzerland, Argentina, Bolivia, Brazil, Chile, Colombia, Costa Rica, Ekuadaor, Honduras, Mexico, Panama, Peru, Uruguay, India, Indonesia, Malaysia, Pakistan, the Philippines, Sri Lanka, Australia, and new Zealand. Of all the countries he had concluded their negative impact treatment tax amnesty that feelings of injustice and anger of

34 Al-Suyuthi. Juz 2. p. 105. 
taxpayers who have been obedient to report his tax liability. ${ }^{35}$

Currently, Indonesia has three time doing tax remission since 1984. Before tax amnesty in 2016-2017 Indonesia did the sunset policy ${ }^{36}$ in 2007-2008 where according Ngadiman and Daniel Huslin in research entitled Pengaruh Sunset Policy, Tax Amnesty, dan Sanksi Pajak Terbadap Kepatuban Wajib Pajak. (Studi Empiris di Kantor Pelayanan Pajak Pratama Jakarta Kembangan), was based on the results of data analysis known that sunset policy and no significant negative effect on tax compliance. ${ }^{37}$ This means that with the removal of sanctions policy against those who do not pay taxes properly, does not necessarily make tax compliance be increased.

Where Güneú Çetin Gerger in 2012 to do research with title Tax Amnesties and Tax Compliance in Turkey, published in the International Journal of Multidisciplinary Thought. In his research, Gerger explained the relationship of tax compliance and tax amnesty by using analysis of the empirical results of a survey done in Turkey. Tax amnesties are used by the Turkish government with the purpose of generating revenue for the country's economic pressures, including political

35 Safri, "Efektifitas Program Tax Amnesty Dan Faktor Keberhasilannya: Pembelajaran Dari Negara-Negara Yang Pernah Menerapkan.”

36 Amenities elimination of tax administrative sanction in the form of interest as stipulated in Law No. 28 of 2007.

${ }^{37}$ Ngadiman and Daniel Huslin, "Pengaruh Sunset Policy, Tax Amnesty, Dan Sanksi Pajak Terhadap Kepatuhan Wajib Pajak (Studi Empiris Di Kantor Pelayanan Pajak Pratama Jakarta Kembangan)," Jumal Akutansi XIX, no. 02 (2015): 225-41. and financial concerns. However, the frequent recurrence of the tax amnesty, proved to have a negative effect on the attitudes and behavior of taxpayers. Taxpayers who are expected to be instead tend amnesty doing something towards tax evasion. The negative effects of the tax amnesty on the attitude and behavior of the taxpayers also have led to a reduction in their tax payment compliance behavior. ${ }^{38}$

This is also in line with the results of the research entitled Khoiril Tax Amnesty and Moral Hazard: Reformulation Study of Tax Amnesty Act 2016 To Preventing Moral Hazard taxpayer. According to happen some betuk moral hazard in policy enforcement of tax amnesty, such as condition monitoring of disability (hidden action) where the tax authorities can not access and oversee all property taxpayer, the conditions of undesirable behavior, production (the unwanted behavior) which taxpayer follow tax amnesty program just to take advantage alone without based on good faith. Then there is also undesirable outcome (impact) production Taxpayer only reveal his property in part only. 39

\section{Muslim Economist South Kalimantan on 'Clean Up' Money on Tax Amnesty}

\footnotetext{
38 Guneu Cetin Gerger, "Tax Amnesties And Tax Compliance In Turkey," International Journal of Multidisciplinary Thought 2, no. 3 (2012): 107-13.

39 Khoiril, "Taz Amnesty Dan Moral Hazard: Studi Reformulasi Undang-Undang Tax Amnesty 2016 Untuk Mencegah Moral Hazard Wajib Pajak.”
} 
With the tax amnesty involves recognizing a capital flight out of the country, both treasure legal and illegal. From the facilities acquired by the taxpayer at the top, the government will 'clean up' and will not press preliminary evidence the existence of the treasure. That is allegedly partly a money laundering 40 the result of unlawful acts such as corruption, illegal trafficking of drugs, weapons, and human trafficking ${ }^{41}$, will be ignored.

Regarding this facility Hartin Anisah Umi said, “True, it's like as we clean up money from all over the place." Similarly with Noval who saw there is a loophole ${ }^{42}$ that can be used by money laundering actors, he said, "the weak tax amnesty in my opinion is there. No longer see where the money is, where it is legal or not. Until the initial goal was to improve the economy or economic growth, the status of the money was legalized, it was considered clean money even

${ }^{40}$ Money laundering is an act attempts to conceal or disguise the origin of money or Wealthproceeds of crimethrough various financial transactions of money or assets that it looked as if it came from a legitimate activity / legal. In general, criminals try to hide or disguise the origin of the assets that are the result of a criminal act in various ways so that assets difficult to trace the proceeds of crime by law enforcement officials so as to freely utilize the assets both for the activities which legally or illegally. See Law of the Republic of Indonesia Number 8 of 2010 on the Prevention and Eradication of Money laundering

${ }^{41}$ Human trafficking or trafficking are all transactionbuying and selling of humans with the purpose of human exploitation. Exploitation includes at least; prostitution (exploitation of prostitution) of others or other such forced labor or services, pebudakan or practices similar to slavery, servitude or the removal of organs

${ }^{42}$ Loophole or legal loopholes, is a weakness or leniency in the law that could be used for the benefit of mankind. Loophole is meant by Noval is a legal loophole that is often used to pay less tax than they should, but it does not violate the law. though it was indicated that money had activities contrary to the law."

The opinion that withdrawing income from prohibited matters is tantamount to preserving, helping or justifying disobedience in accordance with al-zzIzz Ibn 'Abd al-Salam and his book Qawa'idu al-Ahkam fi Masholih al-Anam,

$$
\begin{aligned}
& \text { فصل: في بيان وسائل المفاسد } \\
& \text { يختلف وزن وسائل المخالفات باختلاف رذائل المقاصد } \\
& \text { ومغاسدها، فالوسيلة إلى أرذل المقاصد أرذل من سائر } \\
& \text { الوسائل، فالتوسل إلى الجهل بذات الله وصفاته، أرذل من }
\end{aligned}
$$

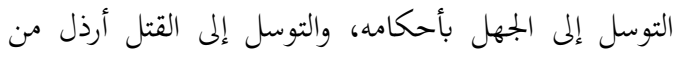

$$
\begin{aligned}
& \text { التوسل إلى الزنا، والتوسل إلى الزنا أقبح من التوسل إلى أكل } \\
& \text { بالباطل، والإعانة على القتل بالإمساك أقبح من الدلالة } \\
& \text { عليه، وكذلك مناولة آلة القتل أقبح من الدلالة عليه، والنظر } \\
& \text { إلى الأجنبية حررم لكونه وسيلة إلى الزنا، والخلوة بها أقبح من } \\
& \text { النظر إليها، وعناقها في الخلوة أقبح من الخلوة بها، والجلوس } \\
& \text { بين رجليها بغير حائل أقبح من ذلك كله، لقوة أدائه إلى } \\
& \text { المفسدة المقصودة بالتحريم. وهكذا تختلف رتب الوسائل } \\
& \text { باختلاف قوة أدائها إلى المفاسد، فإن الشهوة تشتد بالعناق } \\
& \text { بحيث لا تطاق، وليس كذلك النظر، والتفسير أقبح من ذلك } \\
& \text { كله لقوة أدائه إلى الزنا، وكلما قويت الوسيلة في الأداء إلى }
\end{aligned}
$$

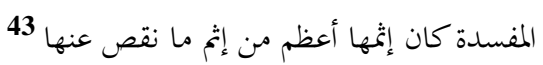

Whereas Muhaimin argued, "for Indonesian law does not differentiate, where is the tax taken, whether it is illegal or not. So do not question how to get it, the results are not questioned where the treasure is." 44 It's different

\footnotetext{
43 Izz al-Din Abdul Aziz bin Abdul Salam, Qawa'idu AlAbkam Fi Masholih Al-Anam (Dar Al-Kitab Al-'alamiyah, n.d.). p. 126-127.

${ }^{44}$ Interview with Muhaimin.
} 
with Fatrya who said, "Consideration is only in terms of the legal suitability of the state, so we don't consider the origin as in the religious side. The result of winning gambling, the result of corruption. Maybe the important consideration is to enter the funds first into the country, then monitoring them. See more maslahat on this regulation." 45

Similarly, Syahrituah argued, "(this policy) was pragmatic, the main objective was money in Indonesia. Political economy, Corruption Collusion Nepotism (KKN), the case of economic law, where money that has been withdrawn in Indonesia means clean and recognized, no longer see where the money came from. Even though the existence of money abroad is also not affordable (cannot be taken or tried). Although there are actions to demand or take back the money that is "washed", there is no achievement either. The principle is that there is a potential for us to clean up "haram" money. But the government must be committed to fairness, to defend its people, not easily fooled by the system." 46

Whereas Handry said, "there will indeed be a stowaway coming in. Like money from illegal business or other dirty money. But in my opinion it won't be much. Of course, more of them have real companies. In terms of person, at least up to 1000 (people) in

${ }^{45}$ Interview with Fatrya Putra.

${ }^{46}$ Interview with Syahrituah Siregar.
Indonesia. In this case we are realistic, it is impossible for all grasses to be uprooted, but this is a better choice than having to lose the potential of money." 47

Still having a similar opinion, Mahmud said that, "there is an income that is not reported abroad which is more difficult than forgiving the person for entering his money domestically. For example, the funds were obtained illegally, that's one mistake, than when someone put abroad, and that's two mistakes. So if a tax amnesty is carried out, for example, the fund is taken from an illegal method, but if it is used for benefit, the error is only one, but the funds can still be utilized. I think that the consideration is that it will be done again. This choice is not good with very bad, so we choose the less good. If the choice is not good and good then of course we choose the good." 48

In connection with the view of benefit, Lutpi Sahal argued "in relation to the maslahab to Indonesia, for public facilities in Indonesia, the halal-haram problem (the source of property that is forgiven by the tax amnesty program) essentially so as not to be eaten, so if for public purposes such as roads, bridges and others then used is not a problem.." 49

Differences of opinion regarding the taking of tax from sources that are not known to the law of the object -

\footnotetext{
47 Interview with Muhammad Handry Imansyah.

${ }^{48}$ Interview with Mahmud Yusuf

${ }^{49}$ Interview with Lutpi Sahal
} 
halal or haram, from legitimate or illegal activities - also occur to Muslim scholars such as Ibn Hajar and Ibnul Mundzir. Ibn Hajar said, nya the principle is, the person who is known that his property is halal, then the gift may be accepted; while the person who is known that his property is haram, then the gift must be rejected. As for doubt, it is better to reject it for the sake of caution. ' Whereas according to Ibnul Mundzir, yang people who are loose in this matter reason that even though Allah said about Jews, Q.S. AlMa'idah/5: 42,

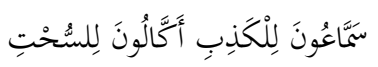

"They are listeners of a lie, devourers of what is forbidden" 50 , but the Prophet once pawned his armor to a Jew while he realized that he was a Jew. Likewise the Prophet took taxes from them, even though it was realized that most of their assets came from liquor, pigs and illegal business. ${ }^{51}$

From a more lenient opinion on tax collection from the results of trade in objects which in the eyes of Sharia are prohibited, more South African Muslim economists finally have the idea of not taking taxes from there. Either the Messenger of Allah or the Companions continued to take taxes from the infidels whose livelihoods made illegal trade in the law of Islam. Therefore, considering that this is also included in the public interest, again the South Kalimantan Muslim

${ }^{50}$ Departemen Agama RI, Alquran Dan Terjemahannya. p. 116. 51 Musthafa Al-'Adawy, Fiqh Akhlak, ed. Salim Bazemool and Taufik Damas (Jakarta: Qisthi Press, 2005). p. 80. economists consider the greater benefit that will result from this tax amnesty policy.

In a more positive view, tax amnesty gives big hopes for increasing tax sector revenues and increasing the number of taxpayers and increasing taxpayer compliance. Parties who have been stowaways of development or parties who have enjoyed the results of development, but have not provided tax payments properly, will be moved to immediately implement pending obligations. Furthermore, determining who is eligible to join this program is important to be specifically determined so that there will be no dispute behind the day, especially regarding who is entitled and not entitled to amnesty. More important than that is to avoid "free riders" from this policy. ${ }^{52}$

\section{Opinion of South Kalimantan Muslim Economist on Treatment of Unrealized or Lesser Assets.}

In accordance with Law Number 11 of 2016 concerning Tax Amnesty, if in the event that the Taxpayer has participated in the tax amnesty program and has obtained a Certificate then found data and / or information regarding the assets that have not been or are not disclosed in the Statement, the property is considered as additional income received or obtained by the

\footnotetext{
52 Sekti Widihartanto and Herru Widiatmanti, “Tax Amnesty Dan Faktor Penentu Keberhasialannya: Pelajaran Dari Beberapa Otoritas Pajak," Tax Law Design and Policy Series (Jakarta, 2016). p. 7.
} 
Taxpayer when it is found no later than 3 (three) years after the Act comes into force. Then the assets will be subject to additional tax administration fine in the form of an increase of $200 \%$ (two hundred percent) of income tax that is not or less paid. This means that the fine given are double the amount of income tax that is not or less paid.

Regarding this, the Muslim economists of South Kalimantan have different views. Fatrya Putra said, "Given the opportunity to be used as a fine of $200 \%$ (two hundred percent) is something natural. If the fine are not too heavy, then people think they don't have to report their assets and do not want to participate in tax amnesty." Likewise with Mahmud who argued, "tax amnesty is not new in Indonesia, but why failed? Because the sanctions are not implemented properly. Determination of the $200 \%$ fine, so that it can run well. This fine is so that there is compliance and effectiveness of the law." 53

In line with the thoughts of Fatrya and Mahmud, Noval said, "the threat of $200 \%$ (two hundred percent) is not a problem, a fine or a good penalty so that the obedient Taxpayer reports correctly his wealth report." 54 Agreeing with that Muhaimin argued, "The fine are legitimate, the rules are the government, whatever the penalty are, the tools are the Law." 55 Likewise Lutpi, who views this as for the policy

53 Interview with Mahmud Yusuf.

${ }^{54}$ Interview with Nofal.

${ }^{55}$ Interview with Muhaimin. to run as expected, he said, "the other aim of this enormous penalty is to threaten not to play around in this policy, so that the Taxpayer is afraid and reports correctly and indeed must report (property)." 56

This corresponds to the example of the story told by Al-Ghazali about some of the ulamas in the book Imam Shatibi, that at that time there was one of the sultans (who at that time ruled), then the sultan asked about his messing around during the day of Ramadan. The legal decision is that the sultan must fast two months in a row. When the sultan came out there were some jurists who followed him to ask again the legal decision. They say, "People who are able to free slaves, how can they move to a fine of fasting, even though fasting is a difficult job, while the sultan has countless slaves". The cleric then said to them, "if I tell him" you must release slaves ", then he will underestimate that and he will free the slaves continuously. The fine of freeing slaves will not deter him, but he will be deterred by fasting two months in a row." 57

Likewise with the opinion of Khulafaurrasyidin who decided to give fines to workers. Ali r.a. said, "it will not be good for humans but with things like that". If there are no fines on them, even though it is needed, it will cause two things; 1) there is no production at all and 2) assets will

\footnotetext{
${ }^{56}$ Interview with Lutpi Sahal.

${ }^{57}$ Asy-Syatibi, Al- ¿`tishâM. h. 600.Asy-Syatibi, Al- i’tishâm Juz. 3. p. 11.
} 
disappear and there will be no safeguards so that treason is possible. So the fine is a maslabah. This is the meaning of the words of Ali r.a. that. Imam Syatibi said that we cannot say that this is actually part of the damage, which is to give a fine to an innocent person, because it is possible that he is not destructive or negligent, so this is the wrong type of treatment (giving a fine). Because according to him, if there is a clash between maslahat and mudharat, then you should see the difference. ${ }^{58}$

In line with the ulama's decision, a large fine is solely for the effectiveness of the policy, so that the government program runs well and the Taxpayer follows in compliance with the tax amnesty activities. Because the sentence should prevent everyone from doing evil before the crime occurs. And if the crime has occurred then the sentence should educate the criminal and prevent others from doing the same thing and take the means. Based on this, it is in accordance with the expressions of scholars about punishment:59. إنا موانع قبل الفعل زواجر بعدأ

But Hartin believes that a policy that has a sanction of $200 \%$ (two hundred percent) must first think of the small people, she said "the policy of tax amnesty which has a fine of $200 \%$ (two hundred percent) should be well socialized well to the public. I, for

${ }^{58}$ Ibid. h. 18.; Asy-Syatibi, Al I'tisham. p. 665.

${ }^{59}$ Faisar Ananda Arfa, "Denda Sebagai Alternatif Hukuman

(Kajian Hukum Islam Kontemporer)," Analytica Islamica 3, no. 1 (2014): 61-72. example, a civil servant (civil servant) is of course easier because it is facilitated properly. But what about those who are Micro, Small and Medium Enterprises (UMKM) or lower class workers? They are also affected by tax amnesty (sanctions of two hundred percent if they do not report correctly). This policy should be seen again not to distress the poor." Meanwhile Hudaya argued that the fine of $200 \%$ (two hundred percent) was excessive, he said "even though both are in the field of muamalah, because Allah regulates zakat only $2.5 \%$ then we make the rules tax higher than $2.5 \%$. We make rules that are higher than God's rules." 60

Likewise with Syahrituah who considers it will not produce something even though there is a penalty of $200 \%$ (two hundred percent) if the system of taxation and our economic system is not correct. He said, "Tax intensification and extensification, the application of tax is tightened (administrative sanctions two hundred percent). Steps like this are actually pragmatic. Not sustainable. Not yet ready for our society, this is actually for tax amnesty. The policy (tax amnesty) is of course brilliant, but not in the right system." 61 In line with that, Handry believes that his policy is theoretically good but only the problem of the running system, he said, "how is the empirical problem,

\footnotetext{
${ }^{60}$ Interview with Muhammad Hudaya
}

${ }^{61}$ Interview with Syahrituah Siregar. 
that's another thing, but if it is theoretically then indeed its good." 62

The opinion of the Muslim economists of South Kalimantan who consider that the fine after the tax amnesty ends is from the Al-Quran argument which is the main source of Islamic teachings, there is a verse that is referred to by scholars who do not allow fines, Q.S. Al-Baqarah/2: 188;

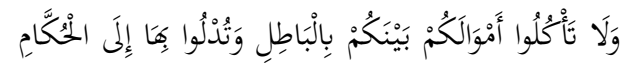

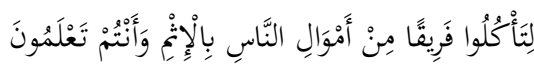

"And do not swallow up your property among yourselves by false means, neither seek to gain access thereby to the judges, so that you may swallow up a part of the property of men wrongfully while you know". ${ }^{63}$

From the verse they say that God forbids us to behave arbitrarily to the property of others. Among the fuqaha there are also differences of opinion about whether fines can be punished or not. Those who contend are justified, a fine is not a good way to eradicate lawlessness, because as if pushing an improper ruler to seize the property of the creator, in addition to the penalty of fine will cause compensation between the rich and poor, because the rich can pay while the poor can not. ${ }^{64}$

The heavy fine from tax amnesty policies, considered by some Muslim Economists in South Kalimantan are

${ }^{62}$ Interview with Muhammad Handry.

${ }^{63}$ Departemen Agama RI, Alquran Dan Terjemahannya. p. 30.

64 Ali Mohammad, "Tinjauan Hukum Islam Terhadap Pelaksanaan Ketentuan Denda Minimum Dan Maksimum Dari UU No. 14/1992 Di Pengadilan Negeri Surabaya" (UIN Sunan Ampel, 1994). p. 21-22 part of arbitrariness. Besides that punishment in Islam must have the principle of meeting the needs of the community and their benefit. If the public's maslahah requires that the punishment be hardened, then the punishment is hardened. But if the maslahah of the community wants to be alleviated, the punishment should be alleviated. Therefore it is not permissible to add sanctions or complicate matters, but punishment must be in accordance with the needs of the community.

\section{Opinion of South Kalimantan Muslim Economist regarding Taxpayers Intending to Transfer Assets into the Territory of the Republic of Indonesia.}

In the tax amnesty program regulated by Law No. 11 of 2016, taxpayers who intend to transfer assets into the territory of the Republic of Indonesia, in addition to meeting administrative requirements as stated in Article 8 paragraph 3, taxpayers must also transfer assets into the territory The Unitary State of the Republic of Indonesia and invests the Assets in the territory of the Unitary Republic of Indonesia for a minimum period of 3 (three) years. In other words, taxpayers cannot transfer their assets outside the territory of the Republic of Indonesia, for a minimum of 3 (three) years from the time they entered the tax amnesty program. 
This means that the government strictly limits the movement of property from its people. Investments that must be freely carried out by each individual then intervened by the state. Looking at this regulation, South Kalimantan Muslim economists like Mahmud said, "The main objective of tax amnesty is to repatriate funds abroad, for domestic development. So there is a capitalist economic system, minimizes intervention in the economy, socialists, on the contrary, are very intervening, while in Islam private ownership is recognized, but if there is for the benefit of many people, the government may regulate it, in this case because wealth becomes mudharat if parked outside country, the government issued a policy of returning Indonesian property to return to Indonesia."65

While Fatrya views this as a very good thing for Indonesia that lacks liquidity, so that it becomes a source of funds that can drive the Indonesian economy. He said, "So for banks this is positive, there are sources of funds that can be rolled back to the community in the form of work loans. The bank must also move the economy from creative banking products so that the funds are not idle and only allowed to remain idle. Again, the point is for the public interest."66 This view is accompanied by Noval's opinion, "the aim is to increase the economy and

${ }^{65}$ Interview with Mahmud Yusuf.

${ }^{66}$ Interview with Fatrya Putra. increase wealth in the country. I think the government's focus now is to return funds even though they will be withdrawn after 3 (three) years." 67

Not seeing a period of 3 (three) years as one so that property flows from abroad to the country as part of the interests of domestic liquidity, Syahrituah considers that this includes political economy where people and groups with economic interests the same has used politics to influence changes that benefit their interests. Syahrituah said, "If it's just the economy, that's a 'what', but if included anyone benefits, that's a 'who', a 'who' means including political economy." 68 In this case, according to him, the state does not benefit more than people who take greater profits from this regulation. Agreeing with Syahrituah, Hudaya also viewed that even though the funds returned to the country had to settle for 3 (three) years in Indonesia according to him the country benefited only a little. They assume that legal withdrawal in the decision of funds that enter the country cannot be transferred abroad is not for the public interest but the interests of a certain number of people.

Interrupting this thought, Handry responded, "What is expected from the money coming back into Indonesia is so that interest rates go down and investment will rise, because of high liquidity. We want a lot of investment,

\footnotetext{
${ }^{67}$ Interview with Muhammad Noval.

${ }^{68}$ Interview with Syahrituah Siregar.
} 
the job will be even higher. That this is a political economy, yes. But we also see this in order to have an impact on the interests of the Indonesian people, later the investment will automatically increase the work area also increases, development also increases faster. Interest decreases, funding of the State Budget (APBN) can also be looser. The government can issue bonds, sukuk, can be cheaper. So you can have fiscal space." 69

Lutpi's view is in line with Handry, Lutpi believes "a good policy to have to invest domestically. This benefits our own country and we need to support this. Self-fund management is very good." ${ }^{\prime 70}$ Likewise with Muhaimin who has the stand to see the positive side of this policy, he said "for the management of the incoming funds, we believe the government can manage well. We think positively." 71

While Hartin views the transfer of assets into the country and having to stay in domestic investment for 3 (three) years is a form of coercion and pragmatic regulations that do not solve economic problems in Indonesia. She argued "with the large amount of funds abroad, the government should understand that people do not want to invest domestically. Why? Because we don't manage it properly. Then if we want to invest in the country, there are investment barriers which people think better I just invest my money outside.

${ }^{69}$ Interview with Muhammad Handry.

${ }^{70}$ Interview with Lutpi Sahal

${ }^{71}$ Interview with Muhaimin.
It is the investment facilities in the country that should be made easier. So the root of the problem must be solved." 72

Hartin's opinion is based on the prohibition on the unilateral taking of property by the government as it is in Q.S. Al-Kahfi/18: 79,

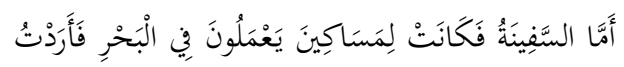

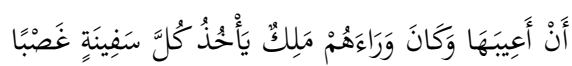

"As for the boat, it belonged to (some) poor men who worked on the river and I wished that I should damage it, and there was behind them a king who seized every boat by force." 73

Even so Hartin did not deny that the flow of funds into the country will have a positive impact on Indonesia's development from the investment that will be generated.

From the various opinions of the South Kalimantan Muslim economists above, we can conclude that in fact they all positively assess the case of putting assets abroad back to Indonesia. The difference is that there are those who see that the main problem is not not wanting to invest in their own country but that investment in Indonesia which is no more attractive results from investing abroad is what makes this policy seem imposing. While others argue that with the forced flow of funds into the country, the movement of development will be more active which will produce a positive stimulus to the

${ }^{72}$ Interview with Hartin Umi Anisah.
${ }^{73}$ Departemen Agama RI, Alquran Dan Terjemahannya. p. 303. 
results of domestic investment. All of that, of course, only wants a large benefit from the entry of assets of Indonesian people from abroad back to Indonesia.

In Islam itself we have the principle of benefit implied in the Qur'an. As in Q.S. Al-Baqarah/2: 219,

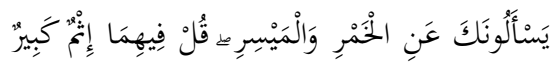

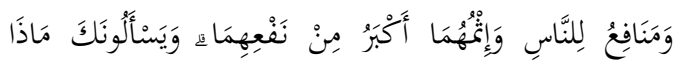

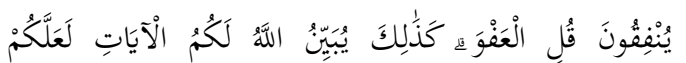

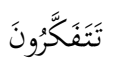

"They ask you about intoxicants and games of chance. Say: in both of them there is a great sin and means of profit for men, and their sin is greater than their profit. And they ask you as to what they should spend. Say: what you can spare. Thus does Allah make clear to the communications, which you may ponder,"'74

If the editors are concerned, the verse above turns out that in taking a drink and playing gambling there is still a benefit but the sin or harm is greater so it is prohibited. Here it appears that Islamic law also adheres to the principle of benefit. The principle of usefulness can also be deduced from the prohibition of redundancy, wasting something, even in the emphasis on the prohibition of wasting something equal to brothers with Satan, according to the word of Allah in Q.S. AlIsra'/17: 26-27,

${ }^{74}$ Departemen Agama RI. p. 35.

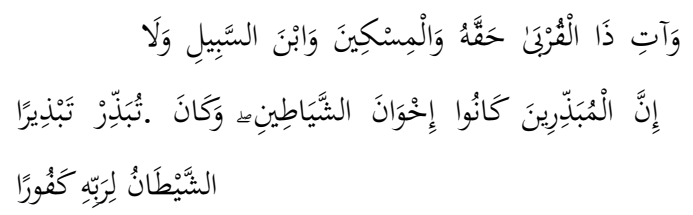

"And give to the near of kin his due and to the needy and the wayfarer, and do not squander wastefully. Surely the squanderers are the fellows of the shaitans and the shaitans is ever ungrateful to his Lord." 75

The prohibition of wasting property is essentially so that the property is used sparingly and carefully so that it is truly useful which is commonly called effective and efficient. The Qur'an as the main source of Islamic law has put forward the principle of benefit as one of its legal principles. This means that since the 7 th century AD Islamic law has adopted the principle of benefit. ${ }^{76}$

This is in line with the tax amnesty policy that adheres to the principle or principle of legal certainty, justice, expediency, and national interests, for which the purpose of the transfer of Assets in the Law of the Republic of Indonesia Number 11 of 2016 concerning Tax Amnesty is to accelerate economic growth and restructuring. Which among others will have an impact on increasing domestic liquidity, improving the Rupiah exchange rate, reducing interest rates, and increasing investment. ${ }^{77}$

\footnotetext{
${ }^{75}$ Departemen Agama RI. p. 285.

76 Muhammad Alim, "Asas-Asas Hukum Modern Dalam Hukum Islam,” Jurnal Media Hukum 17, no. 1 (2010): 151-62.

77 "Undang-Undang Republik Indonesia Nomor 11 Tahun 2016 Tentang Pengampunan Pajak," Pub. L. No. Nomor 11 Tahun 2016 (2016). p. 4.; "Penjelasan Atas Undang-Undang
} 
In addition, in the Islamic economic system, as already said by several Muslim economists in South Kalimantan, there is the ability of intervention from the government in the economic field if it is related to the livelihood of many people. As in the rules,

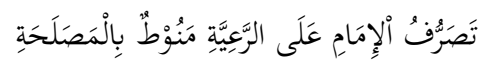

"Priest (government) policy towards the people is based on benefit (maslahah)."

According to Islam, the state has the right to intervene in economic activities carried out by individuals, both to supervise activities and to regulate or carry out various types of economic activities that cannot be carried out by individuals. Although the involvement of the state in economic activities at the beginning of Islam was still lacking due to the simplicity of economic activities at that time. But there are several examples of how to apply to the first Islamic country about the state's interference in economic activities that can be found. One example is the government's interference in returning the distribution of wealth to achieve economic balance among individuals in society. This is what the Messenger of Allah did when he distributed the fa'i (spoils without war) of the Banu Nadir to the Muhajirins only, not to the Ansar, except for two indigent people. $\mathrm{He}$ did this to establish a balance

Republik Indonesia Nomor 11 Tahun 2016 Tentang Pengampunan Pajak" (2016). p. 3. between the Muhajirin people who had left their property in Mecca and fled to bring their religion to Medina, with the Ansar people who had possessions. ${ }^{78}$

This was done by the Prophet in the framework of community life which cannot be separated from the responsibility of the government in controlling and prospering the community. The responsibility of the government in the perspective of Islam has broad flexibility based on the premise that Islam aims to prosper the general public, so that the state in the perspective of Islam can define any function to achieve these goals. ${ }^{79}$

Whereas in terms of achieving the target of increasing domestic liquidity, improving the Rupiah exchange rate, reducing interest rates, and increasing investment - which is the goal of the tax amnesty policy by transferring assets from abroad to the country, according to Muslim economists in South Kalimantan, the country has done its function well and the policy is not at all contrary to the Islamic economic system. This is in line with Sidiqi's thought which classifies the function of the state in Islamic perspective regarding the derivative function of shari'ah based on ijtihad according to social and economic conditions at a certain time which includes 6 functions; a) environmental protection, b) provision of means of

\footnotetext{
78 Indra Hidayatullah, "Peran Pemerintah Di Bidang Perekonomian Dalam Islam,” DINAR 1, no. 2 (2015): 77-89. p. 81.

${ }^{79}$ Hidayatullah. p. 79.
} 
public interest, c) research, d) provision of subsidies to certain private activities, e) expenditure needed for policy stability, and f) capital collection and economic development. ${ }^{80}$

\section{Conclusion}

The Muslim economists of South Kalimantan have different views on the tax amnesty policy. Those who approve this policy have the basis that the policy of the imam (government) towards the people is based on benefit. They view that the tax amnesty policy will be more difficult if it is not forgiven by the delayed tax payment, so that the state cannot use the funds for the benefit of the public at large. Based on the results of studies that have been stated earlier, author draw conclusions from the Muslim economics of South Kalimantan differing opinions regarding tax as one of Indonesia's main income. Some of them agreed and others refused. The argument of Muslim economists in South Kalimantan who agree with tax amnesty is that in the tax collection there is a public maslahah, namely for the benefit of the common people.

Therefore, taking tax amnesty is permissible. In addition, they also put forward the arguments of naqli (the Qur'an and hadith) which instruct the faithful to obey the leader, even if the leader takes the property of his people. The South Kalimantan economists who rejected tax amnesty reasoned that it's were something that was not in the Islamic economic system. Except for that, sources of state income other than tax are considered to have not been optimally optimized so that emergencies as one of the requirements for tax collection are irrelevant.

The South Kalimantan Muslim economist who did not approve the tax amnesty policy stated the reason that in the tax amnesty system there were injustices, namely those who had not obeyed were even forgiven, while those who obeyed and obeyed taxes were not given appreciation. This resulted in taxpayers and public trust in the government being reduced. Another reason is that tax amnesty will have a negative impact on society, namely making the community non-taxcompliant with the assumption that one day there will be a policy of forgiveness again.

\section{Bibliography}

Al-'Adawy, Musthafa. Fiqh Akblak. Edited by Salim Bazemool and Taufik Damas. Jakarta: Qisthi Press, 2005.

Al-Ghazali. Al-Mustashfa Min Ilmi Ushul. 1st ed. Beirut: Al-Resalah Publishing House, 1997.

Al-Suyuthi, Imam Jalaluddin. Husnul Mubadharah Fi Tarikh Misra Wal Qabirah, n.d.

${ }^{80}$ Hidayatullah. 79-80. 
Alim, Muhammad. "Asas-Asas Hukum Modern Dalam Hukum Islam." Jurnal Media Hukum 17, no. 1 (2010): 151-62.

Amiruddin, and Zainal Asikin.

Pengantar Metode Penelitian Hukum. Jakarta: Grafindo Persada, 2010.

An-Naisaburi, Muslim bin al Hajjaj bin Muslim bin Kausyaz al-Qusyairi.

Shahib Muslim. Dar Al Mughni, 1998.

An-nasai, Abu Abdurrahman Ahmad bin Syua'ib bin Ali. Mukhtabar Min Sunan Nasa'i. Riyadh:

International Ideas Home, n.d.

Arfa, Faisar Ananda. "Denda Sebagai

Alternatif Hukuman (Kajian Hukum Islam Kontemporer)." Analytica Islamica 3, no. 1 (2014): 61-72.

Asy-Syatibi, Abu Ishaq Ibrahim bin Musa bin Muhammad Al Lakhmi. Al- ïtishâM. Edited by Edy Fr and Fajar Inayati. Jakarta: Pustaka Azzam, 2006.

—. Al-i'tishâm Juz 3. Dar Ibnu Al Jawzi, 2008.

At-Tirmidzi, Muhammad bin Isa.

Sunan Tirmidzi. Riyadh: Maktabatu Al Ma'arif, n.d.

"Belajar Pajak | Direktorat Jenderal Pajak." Accessed October 9, 2017. http://www.pajak.go.id/content/ belajar-pajak.

Bukhari, Muhammad bin Ismail Al.
Shahih Bukhari. Beirut: Dar Ibn

Katsir, n.d.

Departemen Agama RI. Al-Qur'an Dan

Terjemahannya. Semarang: Toha

Putera, 1989.

Djazuli, A. Kaidah-Kaidah Fikih Islam. Jakarta: Kencana, 2007.

Gerger, Guneu Cetin. “Tax Amnesties And Tax Compliance In Turkey." International Journal of

Multidisciplinary Thought 2, no. 3 (2012): 107-13.

Hidayatullah, Indra. "Peran Pemerintah Di Bidang Perekonomian Dalam Islam." DIN AR 1, no. 2 (2015): 77-89.

Khallaf, Abdul Wahhab. Ijtihad Dalam Syariat Islam. Edited by Rohidin Wahid. Jakarta: Pustaka AlKautsar, 2015.

Khoiril. “Taz Amnesty Dan Moral Hazard : Studi Reformulasi Undang-Undang Tax Amnesty 2016 Untuk Mencegah Moral Hazard Wajib Pajak." Surakarta, 2017.

Mohammad, Ali. "Tinjauan Hukum Islam Terhadap Pelaksanaan Ketentuan Denda Minimum Dan Maksimum Dari UU No. 14/1992 Di Pengadilan Negeri Surabaya." UIN Sunan Ampel, 1994.

Narbuko, Cholid, and Abu Achmadi. Metodologi Penelitian. Jakarta: Bumi Aksara, 2001. 
Ngadiman, and Daniel Huslin.

"Pengaruh Sunset Policy, Tax

Amnesty, Dan Sanksi Pajak

Terhadap Kepatuhan Wajib Pajak

(Studi Empiris Di Kantor

Pelayanan Pajak Pratama Jakarta

Kembangan)." Jurnal Akutansi

XIX, no. 02 (2015): 225-41.

Penjelasan Atas Undang-Undang

Republik Indonesia Nomor 11

Tahun 2016 Tentang

Pengampunan Pajak (2016).

Ragimun. "Analisis Implementasi

Pengampunan Pajak (Tax

Amnesty) Di Indonesia." Badan

Keuangan Fiskal Kemenkeu RI, n.d.

Safri. "Efektifitas Program Tax

Amnesty Dan Faktor

Keberhasilannya: Pembelajaran

Dari Negara-Negara Yang Pernah

Menerapkan." Jurnal Mitra

Manajemen 8, no. 2 (2016): 105-20.

Salam, Izz al-Din Abdul Aziz bin

Abdul. Qawa'idu Al-Abkam Fi

Masholih Al-Anam. Dar Al-Kitab

Al-'alamiyah, n.d.

Undang-Undang Republik Indonesia

Nomor 11 Tahun 2016 Tentang

Pengampunan Pajak, Pub. L. No.

Nomor 11 Tahun 2016 (2016).

Widihartanto, Sekti, and Herru

Widiatmanti. “Tax Amnesty Dan

Faktor Penentu Keberhasialannya:

Pelajaran Dari Beberapa Otoritas

Pajak." Tax Law Design and

Policy Series. Jakarta, 2016. 